\title{
Civilizace Nialla Fergusona: Kritika
}

\section{Niall Ferguson's Civilization: A Critique}

\author{
Jakub Mareš
}

\begin{abstract}
Abstrakt
Velká divergence (tj. proč evropský pokrok překonal zbytek světa) je významné téma civilizačních studií s přesahy do eticko-politických diskuzí. Fergusonova Civilizace: Západ a ti ostatní přináší vlastní řešení této otázky - šest klíčových výhod Západu. Tento článek se pokouší ukázat, že Fergusonovo pojetí nejenže je otevřeně politické a má problematickou vnitřní konzistentnost, ale rovněž odporuje současnému historickému vědění.
\end{abstract}

\section{Klíčová slova}

Niall Ferguson, civilizace, Velká divergence

\begin{abstract}
Great divergence (i.e. why Europe progressed faster than anyone else) has an important place in civilization studies as well as political and ethical ramifications. Ferguson's Civilization: The West and the Rest solves this problem by positing six key advantages of the West. This article aims to show that this approach is not only openly political and problematic in terms of internal consistency, but also unsupported by contemporary historical science.
\end{abstract}

\section{Keywords}

Niall Ferguson, civilization, Great divergence 
Jedna z velkých otázek civilizačních studií je otázka proč Západ? Proč má moderní technologická civilizace svou kolébku v západní Evropě a nikoliv třeba v okolí velkých čínských řek nebo v Pandžábu? Tato otázka není prakticky nikdy posuzována jako apolitické výzkumné téma. Naopak, teoretikům západního supremacismu je zjevný fakt, že základem globální civilizace se stala civilizace západní, která po dlouhou dobu ostatní civilizace zde podrobila, onde vyhubila, důkazem toho, že právě tato civilizace narazila na „morální zlatou žílu“ - že její normy, pravidla a hodnoty byly takové, že jí umožnily o míle předstihnout ostatní civilizace. Implicitním obsahem takového názoru je potom obvykle také představa, že současné zpomalování západního náskoku je dáno úpadkem morálních hodnot (z nějakého důvodu to nikdy nemůže být důsledek toho, že i jiné civilizace objevily ty samé hodnoty - dochází ke směšování relativního a absolutního úpadku).

Pro levicověji zaměřené autory potom tato otázka často končí u otázky koloniální viny - pozornost se zaměřuje na to, že Západ úspěšně provedl genocidu amerického kontinentu a brutálně využil bohatství ostatních civilizací k získání nepřiměřené výhody. Tento přístup často jde ve své idealizované formě tak daleko, že vidí Západ jako civilizaci, která narušila poklidnou existenci starých, hluboce duchovních kultur, znásilnila je a apropriovala jejich kulturu do své konzumní a materialistické. Tato základní neshoda probíhající v zásadě na ose pravice/levice má přitom významný dopad do dnešních debat týkajících se globalizace.

Pokud je vzestup či jeho absence civilizace dán její intrinsitní silou, nemá smysl hovořit o tom, že Západ využíváním levné práce třetího světa tyto země drancuje a udržuje v podřízené pozici. Tato pozice je způsobena jen tím, že místní neschopné nebo zkorumpované politické elity aktivně brání tomu, aby zafungoval Ricardiánský model a přinesl těmto státům postupně blahobyt. Pokud je vzestup Západu podložen drancováním LDC, je v zájmu Západu udržovat ekonomický systém tak, aby se třetí svět nemohl z této situace dostat.

V tomto ohledu je jedním z nejvíce citovaných současných autorů Niall Ferguson, který se této otázce věnoval ve svém dokumentárním cyklu Civilization: Is the West History? a na něm založené knize Civilization: The West and the Rest. ${ }^{1}$ Podle něj je západní hegemonie založena na šesti faktorech, „killer apps“ - ekonomické a politické soutěži, vědě, soukromém vlastnictví, pracovní etice, medicíně a konzumerismu. Tyto faktory jsou pro něj výlučným eu-

1 Niall Ferguson, Civilization: The West and the Rest, London: Penguin Books 2012. 
roamerickým vlastnictvím - a euroamerická civilizace se musí postarat o to, aby to tak zůstalo, aby je neztratila a nikdo jiný nezískal výhodu. Podívejme se na těchto šest aplikací blíže:

1. Soutěž - autor argumentuje, že tam, kde byla Čína monolitický politický celek, který zpomaloval inovace, malé státy v Evropě se takto nechovaly a jejich obyvatelé byli motivováni k usilování o zisk pro slávu svou i národa. To vedlo ke vzniku evropského námořního obchodu.

2. Věda - autor argumentuje, že doktrinářská teokracie Osmanské říše znemožnila inovace a klade ji do kontrastu s dvorem Fridricha Velikého.

3. Soukromé vlastnictví - podle autora je dalším důvodem úspěchu Západu ochrana soukromého vlastnictví právem a zákonem. To demonstruje na rozdílu mezi Latinskou Amerikou a USA.

4. Medicína.

5. Konzumerismus.

6. Protestantská pracovní etika.

Ferguson se znepokojeně ptá v zásadě na dvě otázky - máme tyto ctnosti stále? A co se stane s naší výlučností, pokud je budou mít i jiní? Poukazuje přitom především na Čínu, která přijala západní pracovní etiku, koncept soutěže a soukromého vlastnictví.

Autor se snaží varovně zvednout prst a sdělit Západu, že se musí vzpamatovat a znovu se vrátit $\mathrm{k}$ faktorům, které vedly k jeho dominanci. Autor je tak jistě západní šovinista, ale to neznamená, že by si jeho práce nezasloužila pozornost nebo plnohodnotnou kritiku. Jakým způsobem se k takové kritice postavit?

Typická kritika koncepcí podobných Fergusonovým se v dnešní době zaměřuje na to, že „tento přístup je pouze obhajobou partikulární etiky konkrétní společenské třídy“. To může být jistě pravda - Fergusonovy názory velmi přesně odpovídají názorům angloamerických sociálně konzervativních, ekonomicky liberálních vyšších tříd, reprezentovaných v Británii Konzervativní stranou a v USA Republikánskou stranou - ale pouhé demaskování třídních zájmů nepředstavuje dostatečnou kritiku merita jí preferované etiky. Můžeme k této kritice ale přistoupit i jinými způsoby.

První z nich je etické hledisko. Autor v zásadě měří cenu civilizace a jejích hodnot podle toho, zda dávají sílu. To je u křestanského autora poněkud zvláštní. Pokud bychom ale měli být praktičtí, ještě zvláštnější je autorovo pojetí síly, které se měří výlučně oproti ostatním lidským civilizacím. Toto pojetí má smysl v době železné, kdy se s hrozbami jako nemoci nebo pohromy 
nedá mnoho dělat a naopak existence protivníka dává vítaný zdroj politické jednoty, nedává však smysl v době, kdy mezi nejhorší praktické problémy řadíme globální oteplování, pandemie či limitovanost zdrojů. Mohli bychom proti tomuto prrístupu postavit pojetí, kde hodnoty a „apps“ dané civilizace jsou prostě adaptací na její podmínky? Lze si také povšimnout toho, že toto spojení (síla = hodnota) vytvářejí obvykle autoři civilizačních okruhů, které se zrovna cítí silné, jako obhajobu vlastních hodnot - naopak, pokud se civilizace necítí silná, snaží se naznačit, že hodnoty jsou důležitější nežli síla. Př́ílad může být Gándhí.

Dalším možným přístupem je útok na konzistenci práce - je možné nalézt minimálně tři zásadní nekonzistence. Autor např́klad prosazuje asketický protestantský ideál, který chválí práci na úkor volného času a plýtvání a zároveň žádá větší míru konzumerismu. Tyto dvě pozice není snadné udržovat zároveň. Autor považuje soutěž více celků za přínosnou in se - hru s nenulovým součtem. Zároveň k civilizační hře zjevně přistupuje jako k jevu se součtem nulovým - ztotožňuje jiné než první místo Západu s jeho úpadkem a konečnou porážkou. Nejzvláštnější je, že jeho řešení toho, že ostatní civilizace dohání Západ v jeho „6 killers apps“ je prostě silnější přimknutí se k těmto vynálezům, ne hledání nových.

Autor svoji práci představuje především jako dílo, které je správné učit ve školách, aby děti věděly, jaké hodnoty musí dodržovat pro uchování naší civilizace. Nejvhodnějším přístupem bude kritizovat Fergusonovu „Civilizaci“ z historického hlediska - konec konců, podle své vlastní argumentace, pokud je jeho interpretace důvodů západní hegemonie chybná, odsuzuje tím naši civilizaci k úpadku. Z hlediska historického si položíme dvě otázky:

Otázka exkluzivnosti - jsou Fergusonovy „apps“ skutečně platné pouze pro západní civilizaci?

Otázka kauzality - autor používá monokauzální vysvětlení pro „vítězství Západu“. Zároveň pokládá hodnoty za nejvýznamnější proměnnou, která funguje v zásadě jako nezávislá proměnná určující růst. Dobré hodnoty vedou k růstu. Ignoruje přitom ostatní možné proměnné, jakož i jejich komplikované vztahy.

Nemůžeme ignorovat preskriptivní roli autorových „apps“. Jeho teorii je možné pojímat spíše jako „velký příběh“, který ukazuje nějakou sadu hodnot jako nadřazenou - ukazuje, že historicky fungovala. Bohužel, trendy nelze vždy protáhnout do nekonečna a měnící se podmínky mohou způsobit, že přístup, který fungoval dříve, v nových podmínkách fungovat přestane. Proto se budeme zabývat třetí otázkou, otázkou aktuálnosti. 


\section{Otázka exkluzivnosti}

Za nejpravděpodobnějšího vyzyvatele Západu Ferguson označuje Čínu - a zároveň se diví tomu, že Čína nezvítězila. Odpověd' nachází v klasické představě orientální despocie. Je taková představa oprávněná?

Fergusonův bod 1 - Soutěž, je založen na představě, že Čína, nejvyspělejší civilizace až do roku 1500, byla monolitický státní celek, který fakticky nečelil žádným výzvám, Evropa v té době byla složena z relativně malých celků. Zatímco čínští objevitelé (Zheng He) mohli pouze přinést tribut císaři, evropští byli motivování ziskem a snahou přinést prestiž svému malému politickému celku. Evropská kultura tak stimulovala komerční soutěž, kdežto čínská stála na dusivém monopolu imperiální moci.

Tento argument je jistě působivý - velmi podobné teze přednesl ostatně už Wittfogel, nebo v podstatně komplexnější formě Landes. ${ }^{2}$ Jediný jeho problém je, že není založený na realitě. Západní badatelé často podléhají iluzím o Západu, protože je to jediná civilizace, o které mají podrobné a relativně moderní poznatky - ty jsou pak často porovnávány s kusými znalostmi historií jiných civilizačních okruhů, což vede k západnímu pocitu výlučnosti.

Důležitý argument autora je založen na soukromém vlastnictví - tam, kde stát chrání soukromé vlastnictví, dává pobídku k investicím. Pokud neexistuje jistota, že stát bude na soukromé vlastnictví drobných vlastníků brát ohled, nemají tito důvod investovat práci či kapitál. Z dnes známých právních záznamů z období dynastie Čching víme, že majetkové a občanskoprávní spory probíhaly a čínští poddaní čile využívali mezer v zákoně k zajištění vlastních zájmů. Naopak můžeme snadno zpochybnit evropské „bezpečí investic“ - jakého bezpečí požívali Židé, hugenoti??

Co se týká „ducha obchodu“, je snad pravda, že mu konfuciánství nepřálo - podobně jako katolická víra. Podobně jako v Evropě, v Číně byla i jiná vyznání s jiným př́stupem - například buddhistické kláštery představovaly komerční centra, která se věnovala i tak neduchovní činnosti jako provozování zastaváren. ${ }^{4}$ Nejde ani říci, že by státní přístup k obchodu byl despotický

2 Viz David Landes, The Wealth and Poverty of Nations: Why are some so rich and others so poor?, New York: Norton 1999, s. 20-40.

3 Viz Peter Perdue, China in the Early Modern World: Shortcuts, Myths and Realities, Education about Asia 4, 1999, č. 1, s. 21-26: 23.

4 Viz Morris Rossabi, History of China, New York: Wiley-Blackwell 2013, s. 150. 
či utlačitelský - byla známa role daní ve stabilizaci trhu, byl znám význam volného pohybu zboží, služeb a kapitálu. ${ }^{5}$ Míru konzumerismu v Číně za dynastie Ming můžeme vidět např. na popularitě brakové literatury, která se v podobném rozsahu objeví v Evropě až v 19. století. Konzumerismus vyžaduje jistou hospodářskou úroveň a míru jistoty - Čína ji v této době měla, Evropa ne.

Nemá ani smysl mluvit o nějaké drastické ztrátě vynalézavosti - za dynastie Ming došlo k masivnímu zlepšení knihtisku (které umožnilo právě výše zmíněný brak), sepsání první a dlouho největší encyklopedie nebo vynálezu fragmentačního granátu a přenosného plamenometu. ${ }^{6} \mathrm{O}$ poměru námořních sil dobře vypovídá fakt, že až do poloviny 17. století Čína obvykle vyhrávala bitvy proti evropským námořnictvưm - např́klad bitva v zátoce Liaoluo, bitva o Tunmen, bitva u Xicaowan, nebo dobytí pevnosti Zeelandia, která patřila Nizozemské Východoindické společnosti v roce 1662. Č́ínané mimo jiné vyřešili kurděje pěstováním čerstvého jídla přímo na lodích. Reakce Mingů na evropskou metalurgii a zbraně byla především snaha je koupit a naučit se stavět vlastní, což vedlo např́íklad k zavedení kanónů Hong yi pao adaptovaných z holandských zbraní. Konečně se můžeme pozastavit i nad představou jednotné utiskující vlády, která neumožňuje invenci - jednak Čína zdaleka nebyla po celou svou historii jednotná, a potom - sám autor uznává, že za vlády dynastií Tchang a Sung ještě Čína byla tvořivá - byly snad tyto vlády nějak méně monolitní a despotické než ty pozdější?

Ferguson má nepochybně pravdu v tom, že evropští mořeplavci vypluli s vidinou zisku, kdežto čínští zůstali doma - jenže tato vidina zisku se opírala o př́iběhy Marca Pola a jiných cestovatelů o dalekých zemích, mnohem bohatších než Evropa. Naopak čínská politika chaj-tin (zakázané moře) byla součást snahy o stabilizaci Číny v období sužovaném epidemiemi, Mongoly, rebelií rudých turbanư ${ }^{7}$ atd. Důležitý důvod této politiky zřejmě bylo zamezení vývozu cenných zdrojů ze země a oživení vnitřního obchodu. Tato politika zcela selhala, ale označit ji za výplod čínského despotismu je chybné - už proto že předchozí dynastie nic podobného nedělaly. Navíc, v polovině 16. století byl první chaj-tin odvolán.

5 Viz P. Perdue, China in the Early..., s. 25.

6 Viz napřríklad čínský manuál z období Mingské dynastie Huo Long Ching, ve kterém jsou detailně popsány tehdejší zbrojní technologie.

7 Viz Morris Rossabi, History of China, New York: Wiley-Blackwell 2013, s. 235-237. 
Jedna část moderních autorů (Bin Wong, Kenneth Pommeranz) jde tak daleko, že nenachází žádné zásadní rozdíly mezi Čínou a Evropou až do 19. století - ani v obchodním duchu, ani v soukromém vlastnictví, ba ani v celkové životní úrovni. Jejich závěry sice byly zpochybněny, ale přesto můžeme říct, že rozdíly byly zřejmě daleko menší, než Ferguson naznačuje.

Proč tedy k průmyslové revoluci v Evropě došlo a v Číně ne? Současný výzkum není ve fázi, kdy by mohl jednoznačně odpovědět. Jedna z variant je, že Čína se za dynastie Ming pokusila o svůj vlastní koloniální program. Vybrala si za tím účelem svoje slabé sousedy - například Vietnam. Na rozdíl od Španělů v Novém světě zde ale narazila na protivníky na stejné nebo vyšší technologicko-vojenské úrovni než byla její. Zároveň musela opakovaně čelit mimořádně nebezpečným nomádským protivníkům ze severu, což mělo děsivé ekonomické a demografické následky. Kultury, které např. Zheng He objevil, navíc nebyly tak snadno rozvratitelné pomocí násilí a nemocí jako Ameriky ${ }^{8}$ - bylo nutné s nimi obchodovat a zahrnout je do svého systému tributů. To však znemožnilo vznik masivního čínského impéria v kolonizátorském slova smyslu. Vpád Mančuo̊ a vznik mandžuské dynastie Čching potom představoval další rozvrácení struktur a výrazně zhoršil situaci relativně k Evropě.

\section{Otázka kauzality}

Fergusonovo pojetí považuje základní plusy západní civilizace - vědu, tržní hodnoty a soutěživost obecně - za nezávislé proměnné, ze kterých pramení západní úspěch. Je přitom zjevné, že hlavní plus, které v západních hodnotách spatřuje, je jejich praktičnost. Praktičnost ale vždy čelí základnímu dilematu - nutnosti vyrovnávat mezi krátkodobou a dlouhodobou, přičemž dlouhodobá praktičnost, která není i krátkodobě udržitelná, nemá žádnou hodnotu - uvažovat o jednotlivých společenských institucích jako o „motorech pokroku“ postrádá smysl, protože pokrok nikdy není jejich cílem - jejich cílem je řešení současné situace v nějaký moment.

Ferguson hledá „původ západního úspěchu“ a nachází proměnné (sociálního charakteru), které na něj mohly mít zásadní vliv - mezi jeho nejdůležitější patří pracovní etika v duchu starého argumentu Maxe Webera. 
Jinými slovy, jedním z klíčových důvodů úspěchu byla reformace. Podívejme se na to, odkud se reformace vzala.

Reformaci můžeme prohlásit za složitý sociální jev způsobený otřesy tehdejšího obrazu světa a postavení církve v důsledku černé smrti. Zároveň ale musíme uvést demografické charakteristiky černé smrti. 14. století bylo vesměs dobou, kdy tehdejší evropská civilizace dosáhla vrcholu a začínala se propadat směrem do malthusiánské pasti - docházelo $\mathrm{k}$ hladomorům a sociálním nepokojům způsobeným klimatickou změnou a erozí půdy, ale zároveň se jednalo celkově o nejbohatší období v historii post-římské Evropy. Černá smrt, která měla silně usnadněnou práci hustotou zalidnění, hladomory a válkami a intenzitou komunikací, ulevila demografickým tlakům a převrátila vztah práce/zdroje - polí a zlata, na jednoho obyvatele najednou připadalo víc, než bylo možné obdělat a využít. ${ }^{9}$ To způsobilo značné zbohatnutí jednotlivce a vynutilo si vývoj nových technologií, které v celku zvýšily přebytek na hlavu. To umožnilo vznik vzdělanějšsího obyvatelstva (a v takové situaci již má například smysl vynalézat knihtisk). Rozrušení a oslabení systému trojího lidu, vysoká cena práce a narušení monopolu církve výrazně posílily měštanskou třídu a vủbec třídu sebevědomých, kvalifikovaných pracujících - právě jejich ideologií namířenou proti starým pořádkům se později stal protestantismus. Základem protestantské etiky tedy byly materiální podmínky, zpětně vyvolané způsobem jak se lidé chovali za určitých materiálních podmínek ve vrcholném středověku. Můžeme tak vidět, že sice nelze přímo říct, že „hodnoty jsou důsledek materiálna“, ale můžeme říct, že hodnoty jsou důsledek toho, jak se lidé za určitých materiálních a preexistujících sociálních podmínek chovají. Podobně tak je např. moderní sexuální morálka důsledek většího množství vlivů - vynález antikoncepce a moderní medicína (mizí riziko bastardů a sexuálních chorob), snad i anonymita velkoměstského způsobu života v době, kdy velkoměsta představují ekonomická centra diktující kulturu, které zase souvisí s jinými faktory.

Můžeme tedy vidět, že zdaleka není samozřejmé, jaká „app“ povede $\mathrm{k}$ úspěchu v jaké situaci - a ve skutečnosti je možné, že za jiných okolností stejný postup nepovede ke stejným výsledkům.

Evropská morová epizoda nám může osvětlit také jinou oblast, která se dotýká Fergusonovy nekonzistence v dualitě konzumerismus/práce, a to, do jaké míry je technologický pokrok ovlivněn vztahem ekonomických fakto-

$9 \quad$ Viz Ole Benedictow, The Black Death 1346-1353: The Complete History, Woodbridge: Boydell Press 2004, s. 220. 
rů, tj. práce, půdy a kapitálu. Relativní nedostatek faktoru práce často vede $\mathrm{k}$ invencím na poli technologie. Podobná teorie high-level equlibrium trap Marka Elvina je jedním z pokusů o vysvětlení absence průmyslové revoluce v Číně: zatímco Čína měla efektivní propojení ekonomiky nap̌r. pomocí kanálů umožňující vyrovnávání nabídky a poptávky obchodem a velmi levný faktor práce, Británie měla mizernou dopravní sít způsobující často lokální nedostatek zdrojů, což vynutilo vznik železnice a poměrně drahý faktor práce a vedlo $\mathrm{k}$ rozvoji strojů. ${ }^{10} \mathrm{Z}$ existence tohoto problému můžeme vyvodit nepř́ijemné důsledky i pro naši civilizaci - pokud bude (díky globalizaci, později díky robotizaci) cena faktoru práce postupně klesat, můžeme opravdu očekávat udržení dosavadního tempa technologického růstu?

Výše zmíněné defekty jsou obecnou charakteristikou Fergusonovy práce. Naprríklad důvod, proč Osmanská říše zaostala za Západem, vysvětluje kulturním rozdílem mezi doktrinářskými a despotickými Osmany a sekulární a praktickou Evropou. Sice prakticky nelze pochybovat o tom, že Osmanská ř́še sabotovala svo̊j vlastní pokrok např́ílad zákazy knihtisku, ale je nutné také poznamenat, že k tomu měla dobrý důvod. Osmanští sultáni a především ulamá měli možnost sledovat efekty široce dostupného Božího slova a možnost svévolného výkladu - totiž revoluce a války. Díky značné centralizaci moci byli schopni těmto revolučním efektům zabránit prostým zákazem ${ }^{11}$ - na rozdíl od Evropy, kde podobné pokusy např. ze strany Františka I. Francouzského poměrně rychle a neslavně skončily. Další faktor, který mohl přispět k obtížnějšímu uchycení tisku, je povaha arabského písma. Rovněž nezmiňuje multietnickou povahu říše a velké množství relativně silných vnějších nepřátel, což společně způsobilo, že sultán byl nucen hasit problémy v různých částech říše. Zatímco Sulejman Nádherný prováděl tažení v Evropě, byl nucen řešit také povstání v centrální Anatolii, a jedním z důvodů, proč nemohl nadále řešit Evropu, byla válka se Safíjovci. Je také na místě se ptát, co měla Osmanská říše dělat v situaci, kdy evropské státy mohly začít využívat zdroje celého Nového kontinentu, ke kterému Osmanská říše neměla přístup - což bylo v dlouhodobějším horizontu horší o to, že evropský dálkový námořní obchod výrazně zmenšil význam teritoria Osmanské říše jako obchodní křižovatky na cestě mezi Západem a Východem.

10 Viz Mark Elvin, The high-level equilibrium trap: the causes of the decline of invention in the traditional Chinese textile industries, in Willam Willmott (ed.), Economic Organization in Chinese Society, Stanford: Stanford University Press 1972, s. 137-172.

11 Viz Daron Acemoglu - James Robinson, Why Nations Fail: The Origins of Power, Prosperity and Poverty, London: Profile Books 2012, s. 230-235. 
Můžeme se také dohadovat, že postupný úpadek safijovské Persie nemohl stabilitě pozemních obchodních cest nijak prospět. Pro pád Osmanské říše je možné najít jiné vysvětlení. Její výdaje na udržení krátkodobé stability, koherence a rozsahu říše byly takové, že nedávaly prostor pro řešení dlouhodobých problémů a plánování dlouhodobého rozvoje. Toxická politická a vědecká kultura tak byla ze všeho nejvíc důsledkem paranoii z destabilizujících vlivů, která byla ovšem oprávněná.

Monokauzální vysvětlení jsou zrádná. Teze, které předkládá Ferguson, byly v komplexnější podobě předloženy již Landesem - podobně byla uvedena zcela odlišná vysvětlení - například že Evropa měla výhodu v absenci stepních nájezdníků, dostupnosti železných rud, která umožnila vyspělejší metalurgii, významu dostupných zdrojů uhlí v kombinaci s vodní dopravou, výhodu v možnosti námořní expanze díky „tréninkové“ roli Středozemního moře, výše zmíněnou teorii Marka Elvina o vysokoúrovňovém ekvilibriu nebo dokonce svatební zvyky západních Evropanů. Mezi těmito vysvětleními je prakticky vždy možné vybrat některé, které ideologicky vyhovuje, ale velmi těžké rozpoznat jejich skutečný význam. Ferguson vybral takové hodnoty, které odpovídají představám současné konzervativní pravice, a zpětně pro jejich význam nalezl vysvětlení. Na současné úrovni historického poznání není možné jednoznačně říci, že se zcela mýlí v otázce původu západní dominance - jeho představa, že námořní obchod měl vliv na vznik vlastnických práv, je sdílena např. Robinsonem a Acemogluem ${ }^{14}$ - nicméně, podobně by se mohl ptát v roce 800 arabský autor, v roce 1280 Mongol a po velkou část historie Číňan - a jistě by našli vysvětlení popořadě - v islámu (který sjednocuje různá etnika a vytváří přiměřeně obranyschopnou kulturu), mongolských zvycích, tvrdosti a houževnatosti, které umožnily dobýt svět, a konfuciánské filosofii, která umožňuje správu velké řšše - protože poskytuje nutnou homogenitu.

\section{Otázka aktuálnosti}

Fergusonova práce se netají svým morálním apelem - v zásadě ji považuje za dílo, které by se mělo šírit ve školách, aby se napravily nedostatky současného vzdělávacího systému, který dostatečně nevštěpuje žákům žádoucí hodnoty, které vedly k vzestupu naší civilizace.

Hodnoty jakékoliv doby jsou vesměs odpovědí na širší situaci, obvykle fungují pouze v daném kontextu a odpovídají přístupu dominantní skupiny. 
Neexistuje žádná garance, že hodnoty, které byly „na straně pokroku“ v nějaké fázi vývoje, jsou na straně pokroku i dnes. ${ }^{12}$

Hodnoty, které nám Niall Ferguson předepisuje, jsou odpovědí na svět po černé smrti. Ve skutečnosti ale existují mnohem zjevnější paralely mezi současnou situací a situací vrcholného středověku. Není obtížné načrtnout paralely mezi efekty malé doby ledové/eroze půdy kvůli zemědělství a současnými klimatickými problémy nebo najít podobnosti ve zpomalujícím růstu a mizející návratnosti, což může připomínat sekulární stagnaci. Další podobný jev je míra propojenosti, která umožňuje katastrofické selhání šírící se např́íč celým systémem. V takové situaci ale nemá smysl upřednostnit hodnoty, které představují vhodnou odpověd' na zcela jiný svět. Současný svět se např. nepotýká se zbytkovou tyranií starých sociálních pořádků, které se zuby nehty pokoušejí udržet staré, mimořádně nerovné rozdělení - naopak, nacházíme se v době, kdy nerovnost z relativně utěšených hladin od 70. let postupně stoupá a kompenzace pracujících přestala růst spolu s produktivitou. Současný svět představuje civilizaci ve vrcholné formě, ne po vynucené redukci komplexity, obecně známé jako „pád“.

Pokud bychom měli použít Toynbeeho vizi vrcholné podoby civilizace, mohli bychom si povšimnout, že Fergusonův tón je založen na „návratu ke starým hodnotám, které představují recept na úspěch“. Jenže pokud ve vrcholné době př́slušník elit se zdviženým prstem varuje před opuštěním cest otců, jedná se podle Toynbeeho obvykle o snahu dominantní minority (která ve skutečnosti není schopná nalézat nová řešení, která by nepodkopávala její pozici) idealizovat staré instituce a hodnoty, které kdysi fungovaly, ale nepředstavují nijakou odpověd' na diametrálně odlišné otázky nové doby. ${ }^{13}$ Současný svět nám přináší otázky typické pro vrcholné formy civilizace.

Ferguson se neustále snaží hledat zpo̊sob jak uchovat dominanci západní civilizace, ale přitom si odmítá všimnout dvou důležitějších faktů - svět je dnes globálně integrovaný. Západ stál u jeho zrodu, podobně jako Řecko stvořilo helénský svět, případně Čína Vše pod nebesy. Jeho hodnoty se staly jeho neoddiskutovatelnou součástí. Pokud je v současnosti Západ ohrožen ztrátou autenticity, co má ř́kat islám, Indie nebo Rusko? Snažit se hledat komparativní výhodu vůči např. Číně tedy není vůbec civilizační otázkou,

12 To zároveň nabízí možnost, že jiné civilizace mají vlastní killer apps, které budou v současné situaci fungovat lépe.

13 Např. Vegetius Renatus a jeho zarputilé trvání na vojenských ctnostech v době, kdy se Řím vojenskou silou požíral zevnitř. Viz Arnold Toynbee a David Somervell, A Study of History: Abridgement of Volumes I-VI, New York: Oxford University Press 1987, s. 360-375. 
podobně jako otázka soutěže Německa a Francie v 19. století nebyla civilizační otázkou - protože tyto dva celky již nejsou dostatečně oddělené.

\section{Mgr. Jakub Mareš}

Katedra filozofie, Filozofická fakulta, Masarykova univerzita Arna Nováka 1, 60200 Brno, Česká republika

363670@mail.muni.cz 